\title{
Perbaikan kualitas Citra Menggunakan Metode Gaussian Filter
}

\author{
Hery Sunandar \\ STMIK Budi Darma, Jl. Sisingamangaraja No. 338 Medan, Sumatera Utara, Indonesia \\ http://stmik-budidarma.ac.id, Email : herysunandar@gmail.com
}

\begin{abstract}
The image is in the form of variations in the intensity of a pixel that does not correlate with neighboring pixels that are easily seen by the eye because they look different. By doing image smoothing, it is expected that the image will become more visible. In certain cases, smoothing of the image is indeed done to soften the surface of the image, such as removing small details. Gaussian filter is a mask that is also often used for image smoothing is a gaussian smoothing mask. The existence of quality improvements in the image can improve the image that has very low quality with a gaussian filter.
\end{abstract}

Keyword: Quality, Image, Gaussian Filter.

\section{PENDAHULUAN}

Perkembangannya, kian banyak peneliti yang mencoba melakukan kajian pendefinisian terhadap ilmu komputer. Dalam ilmu komputer, data atau informasi tidak hanya dapat disajikan dalam bentuk teks melainkan pula berupa gambar, audio, bahkan video. Gambar atau citra adalah elemen media yang berfungsi dalam penyampaian informasi secara visual. Penggunaan citra dalam kehidupan sehari-hari sebagai media penyampaian informasi, berbagai kebutuhan akan pengolahan citra digital pun timbul. Tidak hanya untuk memberikan efek-efek artistik yang menambah nilai estetika, tapi juga dapat memperbaiki kualitas dari hasil pencitraan itu sendiri (image enhancement). Jenis operasi dalam perbaikan kualitas citra diterapkan untuk meningkatkan kualitas citra dengan cara memanipulasi parameter-parameter pada citra. Salah satu operasi perbaikan kualitas citra adalah penghalusan citra (image smoothing) ${ }^{[3]}$.

Berbagai literatur menunjukkan bahwa penghalusan citra ditujukan untuk menekan derau (noise). Derau pada citra berupa variasi intensitas suatu pixel yang tidak berkorelasi dengan pixel-pixel tetangganya dan mudah dilihat oleh mata karena tampak berbeda. Contohnya, pada sebuah citra, terdapat derau dengan intensitas tinggi yang membuat sebagian informasi dalam citra tersebut tertutupi. Dengan melakukan penghalusan citra, diharapkan citra tersebut menjadi terlihat lebih jelas. Pada kasus tertentu, penghalusan citra memang dilakukan untuk melembutkan permukaan citra, seperti penghapusan detail kecil dan menjembatani celah kecil di garis atau kurva pada citra dengan harapan memperindah citra itu sendiri. Salah satu teknik yang dapat memenuhi tujuan tersebut adalah penghalusan citra dengan filter Gaussian.

\section{BAHAN DAN METODE}

\subsection{Kualitas}

Perbaikan kualitas citra (image enhancement) merupakan salah satu proses awal dalam pengolahan citra (image preprocessing). Perbaikan kualitas diperlukan karena seringkali citra yang dijadikan objek pembahasan mempunyai kualitas yang buruk, misalnya citra mengalami derau (noise) pada saat pengiriman melalui saluran transmisi, citra terlalu terang/gelap, citra kurang tajam, kabur, dan sebagainya. Melalui operasi pemrosesan awal inilah kualitas citra diperbaiki, sehingga citra dapat digunakan untuk aplikasi lebih lanjut, misalnya untuk aplikasi pengenalan (recognition) objek di dalam citra.

\subsection{Citra}

Citra adalah suatu representasi (gambaran), kemiripan atau imitasi dari suatu objek. Citra sebagai keluaran suatu sistem perekaman data dapat bersifat optik berupa foto, bersifat analog berupa sinyal-sinyal video seperti gambaran pada monitor televisi, atau bersifat digital yang dapat langsung disimpan pada suatu media penyimpanan. Meskipun sebuah citra kaya akan informasi, namun sering kali citra yang dimiliki mengalami penurunan mutu, misalnya mengandung cacat atau denois ${ }^{[7]}$.

\subsection{Elemen-Elemen Citra Digital}

Berikut adalah elemen elemen yang terdapat pada citra digital.

1. Kecerahan (Brightness)

Kecerahan (Brightness ) merupakan cahaya yang dipancarkan pixel dari citra yang dapat ditanggap oleh system 
penglihatan. Kecerahan pada sebuah titik (piksel) didalam citra yang merupakan intensitas rata- rata dari suatu area yang melingkupinya.

2. Kontras (Contrast)

Kontrast (Contrast) merupakan sebaran terang dan gelap dalam sebuah citra. Pada citra yang baik, komposisi gelap dan terang tersebar secara merata.

3. Kontur (Contur)

Kontur (Contur) adalah keadaan yang ditimbulkan oleh perubahan intensitas pada piksel-piksel yang bertetangga. Karena adanya perubahan intensitas inilah mata mampu mendeteksi tepi-tepi objek didalam citra.

4. Warna

Warna sebagai persepsi yang ditangkap sistem visual terhadap panjang gelombang cahaya yang dipantulkan oleh objek.

\subsection{Pixel}

Setiap pixel mewakili tidak hanya satu titik dalam sebuah citra melainkan sebuah bagian berupa kotak yang merupakan bagian terkecil (sel). Nilai seluruh pixel haruslah dapat menunjukkan nilai rata-rata yang sama untuk seluruh bagian dari sel tersebut. Pixel merupakan komponen tunggal terkecil dari sebuah citra digital.

Setiap pixel mewakili tidak hanya satu titik dalam sebuah citra melainkan sebuah bagian berupa kotak yang merupakan bagian terkecil (sel). Nilai dari sebuah pixel haruslah dapat menunjukkan nilai rat-rata yang sama untuk seluruh bagian dari sel tersebut. Pixel (Picture Element) adalah nilai tiap-tiap entri matriks pada bitmap. Rentang nilai-nilai pixel ini dipengaruhi oleh banyaknya warna yang dapat ditampilkan. Jika suatu bitmap dapat menampilkan 256 warna maka nilai-nilai pixe/nya dibatasi dari 0 hingga 255. Suatu bitmap dianggap mempunyai ketetapan yang tinggi jika dapat menampilkan lebih banyak warna ${ }^{[11]}$.

\subsection{Resolusi}

Resolusi citra merupakan tingkat detail suatu citra, semakin tinggi resolusi citra maka akan semakin tinggi pula tingkat detail dari citra. Resolusi merupakan salah satu faktor penentu kualitas sebuah citra digital. Tetapi, resolusi bukanlah satu-satunya penentu kualitas dari sebuah citra digital, masih ada faktor lain yang mempengaruhi kualitas dari sebuah citra digital 2.6. Konvolusi

Konvolusi (convolution) adalah sebuah proses dimana citra dimanipulasi dengan menggunakan eksternal mask / subwindows untuk menghasilkan citra yang baru.
Sedangkan Filtering tanpa menggunakan ekternal mask tetapi hanya menggunakan pixel tetangga untuk mendapatkan pixel yang baru.

\subsection{Gaussian Filter}

Mask yang sering pula digunakan untuk penghalusan citra adalah mask penghalusan Gaussian (Gaussian smoothing). Bobot pada mask penghalusan Gaussian mengikuti distribusi normal sebagaimana yang dinyatakan dalam persamaan di bawah ini ${ }^{[3]}$ :

$$
h(m, n)=\frac{1}{2 \pi \sigma^{2}} e^{\frac{-\left(m^{2}+n^{2}\right)}{2 \sigma^{2}}}
$$

Dimana :

1. $\sigma$ adalah nilai deviasi standar distribusi normal yang digunakan. Makin besar nilai $\sigma$, maka makin banyak titik tetangga yang diikutkan dalam perhitungan.

2. $x$ dan $y$ adalah posisi koordinat mask dimana koordinat $(0,0)$ adalah posisi titik tengah dari mask yang mempunyai nilai paling besar/paling tinggi.

3. $\square$ adalah konstanta dengan nilai 3,14 .

4. e adalah konstanta bilangan natural dengan nilai 2, 718281828 .

\section{HASIL DAN PEMBAHASAN}

Dalam analisis ini, data citra yang digunakan adalah citra dengan format bmp. Berikut urutan langkah yang dilakukan penulis dalam analisis penghalusan citra dengan filter Gaussian.

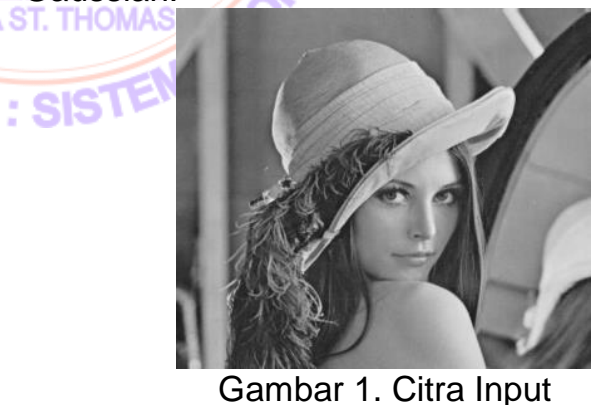

Gambar diperkecil hingga $5 \times 5$ pixel. Kemudian, citra diekstraksi/direpresentasi ke dalam bentuk matriks, sehingga dapat menampilkan nilai intensitas warna dalam setiap pixel-nya.



Gambar 2. Ekstraksi Citra "Lena" 
Setelah mengekstraksi citra, langkah selanjutnya adalah melakukan penentuan filter/mask yang ditentukan dengan distribusi Gaussian 2-D. Pada analisis ini, besar $=1$ dengan besar kernel $3 \times 3$, didapat kernel distribusi Gaussian 2-D seperti berikut ini.

\begin{tabular}{|l|l|l|}
\hline 0.075 & 0.124 & 0.075 \\
\hline 0.124 & 0.204 & 0.124 \\
\hline 0.075 & 0.124 & 0.075 \\
\hline
\end{tabular}

Gambar 3. Distribusi Gaussian 2-D

Langkah berikutnya adalah melakukan proses image filtering dengan menerapkan operasi konvolusi sebagai berikut:

\begin{tabular}{|l|c|c|c|c|}
\hline 123 & 123 & 156 & 156 & 106 \\
\hline 115 & 123 & 177 & 154 & 101 \\
\hline 121 & 90 & 126 & 113 & 146 \\
\hline 106 & 77 & 110 & 118 & 174 \\
\hline 104 & 56 & 128 & 176 & 110 \\
\hline
\end{tabular}

$\mathrm{h}(\mathrm{m}, \mathrm{n})=\left(123^{\star} 0.075\right)+\left(123^{\star} 0.124\right)+$ $\left(156^{\star} 0.075\right)+\left(115^{\star} 0.124\right)+\left(123^{\star} 0.204\right)+$ $\left(177^{\star} 0.124\right)+\left(121^{\star} 0.075\right)+\left(90^{\star} 0.124\right)+$ $\left(126^{\star} 0.075\right)$

$\mathrm{h}(\mathrm{m}, \mathrm{n})=127$

\begin{tabular}{|c|c|c|c|c|}
\hline 0 & 0 & 0 & 0 & 0 \\
\hline 0 & 127 & 142 & 139 & 0 \\
\hline 0 & 112 & 122 & 133 & 0 \\
\hline 0 & 96 & 111 & 133 & 0 \\
\hline 0 & 0 & 0 & 0 & 0 \\
\hline
\end{tabular}

Gambar 4. Hasil Image Filtering

Adapun hasil citra hasil penghalusan menggunakan filter gaussian dengan menghitung nilai standart deviasi dapat dilihat seperti gambar berikut ini :

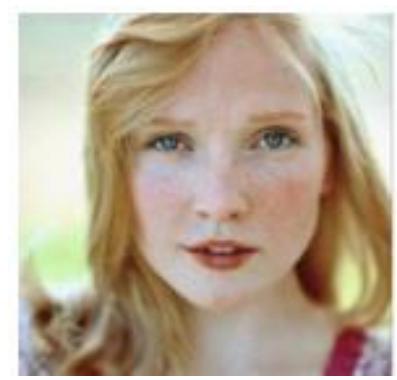

Gambar 5. Girl1.bmp

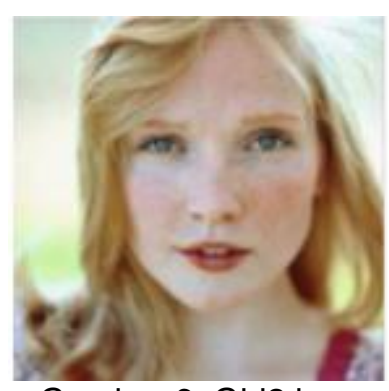

Gambar 6. Girl2.bmp

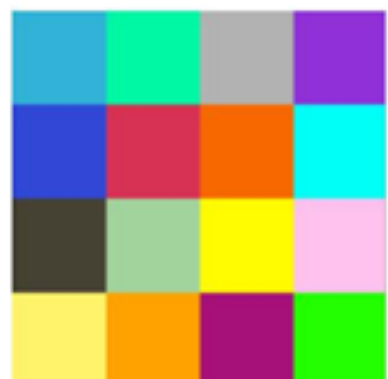

Gambar 7. Clr.bmp

Tabel 1. Penapisan Gaussian

\begin{tabular}{ccccc}
\hline No & $\begin{array}{c}\text { Ukuran } \\
\text { Kernel }\end{array}$ & $\begin{array}{c}\text { Citra } \\
\text { Hasil }\end{array}$ & $\begin{array}{c}\text { Lama Proses } \\
\text { (Detik) }\end{array}$ & Ukuran \\
\hline 1 & 3 & girl1.bmp & 6.4521258 & 762,747 bytes \\
2 & 7 & girl2.bmp & 27.41558833 & 645,697 bytes \\
3 & 3 & clr.bmp & 5.0045773 & 7,053 bytes \\
\hline
\end{tabular}

Dari tabel di atas dapat diketahui bahwa semakin besar standar deviasi dan besar kernel yang dimasukkan, maka permukaan citra akan semakin kabur. Selain itu, pada citra tertentu seperti citra girl.bmp menjadi girl1.bmp, hasil penapisan Gaussian memiliki kapasitas ukuran yang lebih besar dari citra aslinya.

\section{KESIMPULAN}

Adapun yang menjadi kesimpulan berdasarkan permasalahan di atas adalah perbaikan kualitas citra dengan menerapkan filter gaussian sangat baik, semakin tinggi nilai standart deviasi pada citra maka citra tersebut semakin kabur dan semakin rendah nilai standart deviasi maka citra semakin terang atau kualitas semakin baik.

\section{DAFTAR PUSTAKA}

1. Abdul Wahab Solichin. (1990). Pengantar Analisis Kebijaksanaan Negara. Jakarta: Rineka Cipta.

2. Ali, Lukman dkk. (1995), Kamus Besar Bahasa Indonesia. Jakarta: Balai Pustaka.

3. Verma Anurag. Asst. Prof. Abhishek Mishra (2015). Image Compression using 
Gaussian Smoothing Filter and Median Filter, International Journal on Recent and Innovation Trends in Computing and Communication, VOL.3 Issues.11.

4. A.S, Rosa dan M. Shalahuddin. (2011). Rekayasa Perangkat Lunak. Yogyakarta: Informatika.

5. Badudu J.S dan Zain, Sutan Mohammad. (1996). Kamus Umum Bahasa Indonesia. Jakarta: Pustaka Sinar Harapan.

6. Balza Achmad, M. Sc. E. Ir., Kartika Firdausy S. T., M. T. (2005). Teknik Pengolahan Citra Digital Menggunakan Delphi, Yogyakarta: ANDI.

7. Darma Putra. (2010). Pengolahan Citra Digital, Yogyakarta: ANDI.

8. Dessy Purwandani. (2015). Implementasi Metode Gaussian Smoothing Untuk Penghalusan Citra (Image Smoothing), 2301-9425.

9. Gonzalez, R. C., Woods, R. E. \& Eddins, S. L. (2009). Digital Imag Processing Using Matlab. 2nd Edition. Gatesmark Publishing.

10. Mamta Sharma. (2010). Compression Using Huffman Coding, IJCSNS International Journal of Computer Science and Network Security, VOL. 10 No.5.

11. Rinaldi Munir. (2004). Pengolahan Citra Digital dengan Pendekatan Algoritmik, Bandung: Informatika.

12. Wahana Komputer. (2008). Cepat Menguasai Visual Studio NET 2008 Express. Yogyakarta: ANDI. 